\title{
Preserving Food: Freezing Vegetables ${ }^{1}$
}

\author{
Judy A. Harrison and Elizabeth Andress; adapted for use in Florida by Amy Simonne ${ }^{2}$
}

Freezing is an excellent way to preserve fresh vegetables at home. Freezing does not sterilize food; the extreme cold simply retards growth of microorganisms and slows down changes that affect quality or cause spoilage in food.

The quality of frozen vegetables depends on the quality of the fresh products and how they are handled from the time they are picked until they are ready to eat. It is important, also, to start with high-quality vegetables because freezing will not improve the product's quality.

\section{Selecting Freezer Containers}

Before preparing vegetables for freezing, assemble the containers you will use. The selection of containers depends on the vegetable being frozen, personal preference and the types that are readily available. Containers should be moisture-vapor resistant, durable, easy to seal and should not become brittle at low temperatures.
Containers suitable for freezing vegetables include plastic freezer containers, flexible freezer bags and their protective cardboard cartons, or glass canning jars. Foods packed in wide-mouth jars are easier to remove than those packed in narrow-mouth jars.

Some household containers are not recommended for freezing. The cardboard cartons that milk, ice cream or cottage cheese come in are not moisture-vapor resistant enough. Regular (not canning) jars break too easily at freezer temperatures.

\section{Preparing the Vegetables}

Use vegetables at peak flavor and texture for freezing. Whenever possible, harvest in the cool part of the morning and freeze within a few hours. Wash vegetables thoroughly in cold water, lifting them out of the water as grit settles to the bottom of the washing container. Sort according to size for blanching and packing.

1. This document is Fact Sheet FCS 8768, a series of the Department of Family, Youth and Community Sciences, Florida Cooperative Extension Service, Institute of Food and Agricultural Sciences, University of Florida. Publication date: August 2004. Please visit the EDIS Web site at http://edis.ifas.ufl.edu

2. Adapted for use in Florida by Amy Simonne, assistant professor, Food Safety and Quality, Department of Family, Youth and Community Sciences, Cooperative Extension Service, Institute of Food and Agricultural Sciences, University of Florida, Gainesville, FL 32611. With permission, this publication contains the full text of Preserving Food: Freezing Vegetables, edited by Judy A. Harrison, Ph.D., and Elizabeth L. Andress, Ph.D., Extension Foods Specialists, the University of Georgia and Ft. Valley State University, the U.S. Department of Agriculture and counties of the state of Georgia cooperating; and additional information from the National Center for Home Food Preservation website: http://www.uga.edu/nchfp/

The Institute of Food and Agricultural Sciences is an equal opportunity/affirmative action employer authorized to provide research, educational information and other services only to individuals and institutions that function without regard to race, color, sex, age, handicap, or national origin. For information on obtaining other extension publications, contact your county Cooperative Extension Service office. Florida Cooperative Extension Service / Institute of Food and Agricultural Sciences / University of Florida / Christine Taylor Waddill, Dean 


\section{Blanching}

Blanching (scalding vegetables in boiling water or steam for a short period of time) is a must for almost all vegetables to be frozen. Blanching slows or stops the action of enzymes that can cause loss of flavor, color and texture. Blanching cleanses the surface of dirt and organisms, brightens the color and helps retard loss of vitamins. Blanching also wilts or softens vegetables and makes them easier to pack.

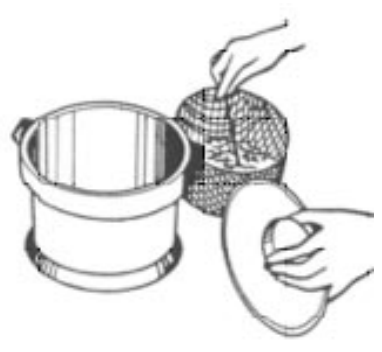

Blanching time is crucial and varies with the vegetable and its size. Underblanching stimulates the activity of enzymes and is worse than no blanching. Overblanching causes loss of flavor, color, vitamins and minerals. See the directions for freezing each vegetable for the correct blanching times.

Water Blanching - For home freezing, the most satisfactory way to heat all vegetables is in boiling water. Use a blancher with a blanching basket and cover, or fit a wire basket into a large kettle with a lid.

Use one gallon of water per pound of prepared vegetables. Put the vegetables in a blanching basket and lower into vigorously boiling water. Place a lid on the blancher and start counting blanching time as soon as the water returns to a boil. Keep heat high for the time given in the directions for the vegetables you are freezing.

Steam Blanching - Heating in steam is recommended for a few vegetables. For broccoli, pumpkin, sweet potatoes and winter squash, both steaming and boiling are satisfactory methods. Steam blanching takes about 1-1/2 times longer than water blanching.
To steam, use a kettle with a tight lid and a basket that holds the food at least three inches above the bottom of the kettle. Put an inch or two of water in the kettle and bring the water to a boil.

Put the vegetables in the basket in a single layer so steam reaches all parts quickly. Cover the kettle and keep heat high. Start counting steaming time as soon as the lid is on. Steam blanch for the time recommended for each vegetable.

Microwave Blanching - Microwave blanching is not recommended. Research has shown that some enzymes may not be inactivated. Flavors could be off and texture and color lost. If you choose to risk low quality vegetables by microwave blanching, work in small quantities, using the directions for your specific microwave oven. Microwave blanching has not been shown to save time or energy.

\section{Cooling}

As soon as blanching is complete, cool vegetables quickly and thoroughly to stop the cooking process. To cool, plunge the basket of vegetables immediately into a large quantity of cold water, $60^{\circ} \mathrm{F}$ or below. Change water frequently or use cold running water or iced water. If ice is used, have about one pound of ice for each pound of vegetables. Cooling vegetables should take the same amount of time as blanching.

Drain vegetables thoroughly after cooling. Extra moisture can cause a loss of quality when vegetables are frozen.

\section{Types of Pack}

Two basic packing methods are recommended for frozen vegetables-dry pack and tray pack. 
Dry Pack - Place the blanched and drained vegetables into meal-size freezer bags or containers. Pack tightly to cut down on the amount of air in the package. Leave 1/2-inch headspace at the top of rigid containers and close securely. For freezer bags, fill to within three inches of the top, twist and fold back top of bag; tie with a twist or rubber band about 1/2- to 3/4inch from the food. This will allow space for the food to expand. Provision for headspace is not necessary for foods such as broccoli, asparagus and brussel sprouts that do not pack tightly in containers.

Tray Pack - Place chilled, well-drained vegetables in a single layer on shallow trays or pans. Place in freezer until firm, then remove and quickly fill bags or containers. Close and freeze immediately. Tray-packed foods do not freeze in a block, but remain loose, so the amount needed can be poured from the container and the package re-closed.

\section{Labeling and Storing}

Label packages with the name of the product and the freezing date. Freeze at once at $0^{\circ} \mathrm{F}$ or lower. Because speed in freezing is important for best quality, put no more unfrozen vegetables into the freezer at one time than will freeze in 24 hours-usually two to three pounds of vegetables per cubic foot of freezer space.

For quickest freezing, place packages against the refrigerated surface of the freezer. After vegetables are frozen, rearrange the packages and store close together. Most vegetables maintain high quality for 8 to 12 months at $0^{\circ} \mathrm{F}$ or lower. Longer storage will not make food unfit for use, but may impair quality.

It is a good idea to post a list of the frozen vegetables near the freezer and to check off packages as they are used. Remember, frozen vegetables should be cooked without thawing. 


\section{Directions for Freezing Vegetables}

\begin{tabular}{|c|c|c|}
\hline Vegetable & Preparation & $\begin{array}{c}\text { Blanching Time } \\
\text { (in boiling water unless } \\
\text { otherwise stated) }\end{array}$ \\
\hline Globe Artichoke Hearts & $\begin{array}{l}\text { Select those with uniformly green } \\
\text { color, compact globes and tightly } \\
\text { adhering leaves. Remove all leaves } \\
\text { and choke or fuzzy portion. The portion } \\
\text { that is left at the base is the heart. Cut } \\
\text { away the stem just below the heart and } \\
\text { trim any woody portions. Wash hearts } \\
\text { in cold water and drain. Blanch, cool, } \\
\text { and drain. Pack, leaving no } \\
\text { headspace. Seal and freeze. }\end{array}$ & 7 minutes \\
\hline Jerusalem Artichokes & See Irish Potatoes & $\begin{array}{ll}---- \\
\end{array}$ \\
\hline Asparagus & $\begin{array}{l}\text { Wash thoroughly, sort by size. Cut in } \\
\text { 2-inch lengths or leave in spears. } \\
\text { Blanch, cool and drain. Package, seal } \\
\text { and freeze. }\end{array}$ & $\begin{array}{l}\text { Small stalks - } 2 \text { minutes } \\
\text { Medium stalks - } 3 \text { minutes } \\
\text { Large stalks - } 4 \text { minutes }\end{array}$ \\
\hline Beans: green or wax & $\begin{array}{l}\text { Select young tender beans. Wash and } \\
\text { remove ends. Leave whole, slice or cut } \\
\text { into 1-inch to 2-inch lengths. Blanch, } \\
\text { cool and drain. Package, seal and } \\
\text { freeze. }\end{array}$ & 3 minutes \\
\hline Beans: lima, butter or pinto & $\begin{array}{l}\text { Select beans ready for table use with } \\
\text { slightly rounded, bright green pods. } \\
\text { Wash, shell and sort according to size. } \\
\text { Blanch, cool and drain. Package, seal } \\
\text { and freeze. }\end{array}$ & $\begin{array}{l}\text { Small beans }-2 \text { minutes } \\
\text { Medium beans }-3 \text { minutes } \\
\text { Large beans }-4 \text { minutes }\end{array}$ \\
\hline Beets & $\begin{array}{l}\text { Wash and sort according to size. } \\
\text { Leave tap root; trim tops leaving 1/2- } \\
\text { inch of stem. Cook in boiling water until } \\
\text { tender. Cool, peel (removing stem and } \\
\text { tap root) and cut into slices or cubes. } \\
\text { Package, seal and freeze. }\end{array}$ & $\begin{array}{l}\text { Cook: } \\
\text { Small beets - 25-30 minutes } \\
\text { Medium beets - } 45-50 \\
\text { minutes }\end{array}$ \\
\hline Broccoli & $\begin{array}{l}\text { Wash and trim. If insects are present } \\
\text { soak } 1 / 2 \text { hour in solution of } 4 \\
\text { teaspoons salt to } 1 \text { gallon of cold } \\
\text { water. Split lengthwise into pieces no } \\
\text { more than } 1-1 / 2 \text { inches across. Blanch, } \\
\text { cool and drain. Package, seal and } \\
\text { freeze. }\end{array}$ & $\begin{array}{l}\text { In water - } 3 \text { minutes } \\
\text { In steam - } 5 \text { minutes }\end{array}$ \\
\hline
\end{tabular}




\begin{tabular}{|c|c|c|}
\hline Vegetable & Preparation & $\begin{array}{c}\text { Blanching Time } \\
\text { (in boiling water unless } \\
\text { otherwise stated) } \\
\end{array}$ \\
\hline Brussels Sprouts & $\begin{array}{l}\text { Select green, firm, compact heads. } \\
\text { Make sure no insects are present. } \\
\text { Trim, removing coarse outer leaves. } \\
\text { Wash and sort. Blanch, cool and drain. } \\
\text { Package, seal and freeze. }\end{array}$ & $\begin{array}{l}\text { Small - } 3 \text { minutes } \\
\text { Medium - } 4 \text { minutes } \\
\text { Large - } 5 \text { minutes }\end{array}$ \\
\hline $\begin{array}{l}\text { Cabbage } \\
\text { (for cooked dishes) }\end{array}$ & $\begin{array}{l}\text { Select fresh, compact heads. Remove } \\
\text { coarse outer leaves. Cut into medium } \\
\text { to coarse shreds, or thin wedges, or } \\
\text { separate head into leaves. Blanch, } \\
\text { cool and drain. Package, seal and } \\
\text { freeze. }\end{array}$ & $1-1 / 2$ minutes \\
\hline Carrots & $\begin{array}{l}\text { Select tender, mild-flavored carrots. } \\
\text { Remove tops. Wash and peel. Leave } \\
\text { small carrots whole. Cut others in 1/4- } \\
\text { inch cubes, thin slices or lengthwise } \\
\text { strips. Blanch, cool and drain. } \\
\text { Package, seal and freeze. }\end{array}$ & $\begin{array}{l}\text { Small, whole - } 5 \text { minutes } \\
\text { Diced, sliced or strips - } 2 \\
\text { minutes }\end{array}$ \\
\hline Cauliflower & $\begin{array}{l}\text { Choose tender, firm, snow-white } \\
\text { heads. Break into pieces about } 1 \text { inch } \\
\text { across. Wash. If insects are present, } \\
\text { soak } 1 / 2 \text { hour in solution of } 4 \\
\text { teaspoons salt to } 1 \text { gallon of cold } \\
\text { water. Drain. Blanch, cool and drain. } \\
\text { Package, seal and freeze. }\end{array}$ & 3 minutes \\
\hline $\begin{array}{l}\text { Celery } \\
\text { (for cooked dishes) }\end{array}$ & $\begin{array}{l}\text { Select crisp, tender stalks, free from } \\
\text { coarse strings. Wash thoroughly, trim } \\
\text { and cut stalks into l-inch lengths. } \\
\text { Blanch, cool promptly, and drain. } \\
\text { Package leaving no headspace. Seal } \\
\text { and freeze. }\end{array}$ & 3 minutes \\
\hline Corn: sweet & $\begin{array}{l}\text { Select ears with plump kernels and thin } \\
\text { sweet milk. Husk ears, remove silk and } \\
\text { wash. }\end{array}$ & ----- \\
\hline $\begin{array}{l}\text { Corn: whole kernel and } \\
\text { creamed }\end{array}$ & $\begin{array}{l}\text { Blanch, cool and drain. For whole } \\
\text { kernel corn, cut corn off cob about } 2 / 3 \\
\text { the depth of kernels. For cream style } \\
\text { corn, cut at } 1 / 2 \text { the depth of kernels } \\
\text { and scrape cob with back of knife to } \\
\text { remove juice. Package, seal and } \\
\text { freeze. }\end{array}$ & 4 minutes \\
\hline
\end{tabular}




\begin{tabular}{|c|c|c|}
\hline Vegetable & Preparation & $\begin{array}{c}\text { Blanching Time } \\
\text { (in boiling water unless } \\
\text { otherwise stated) }\end{array}$ \\
\hline Corn: on the cob & $\begin{array}{l}\text { Sort ears according to size. Small } \\
\text { ears-1-1/4 inches or less in diameter. } \\
\text { Medium ears-1-1/4 to } 1-1 / 2 \text { inches in } \\
\text { diameter. Large ears-over } 1-1 / 2 \\
\text { inches in diameter. Blanch, cool } \\
\text { completely and drain. Package, seal } \\
\text { and freeze. }\end{array}$ & $\begin{array}{l}\text { Small ears - } 7 \text { minutes } \\
\text { Medium ears - } 9 \text { minutes } \\
\text { Large ears - } 11 \text { minutes }\end{array}$ \\
\hline Eggplant & $\begin{array}{l}\text { Wash, peel and slice } 1 / 3 \text { inch thick. } \\
\text { Blanch in } 1 \text { gallon of water containing } \\
4-1 / 2 \text { teaspoons citric acid or } 1 / 2 \text { cup } \\
\text { lemon juice. Cool and drain. Package, } \\
\text { seal and freeze. } \\
\text { For Frying-Package the drained slices } \\
\text { with freezer wrap between slices. Seal } \\
\text { and freeze. }\end{array}$ & 4 minutes \\
\hline $\begin{array}{l}\text { Greens: beet greens, } \\
\text { collards, chard, kale, } \\
\text { mustard greens, spinach or } \\
\text { turnip greens }\end{array}$ & $\begin{array}{l}\text { Select tender leaves. Wash and } \\
\text { remove stems. Blanch, cool and drain. } \\
\text { Package, seal and freeze. }\end{array}$ & $\begin{array}{l}\text { Collards - } 3 \text { minutes } \\
\text { Other greens - } 2 \text { minutes }\end{array}$ \\
\hline $\begin{array}{l}\text { Fresh Herbs } \\
\text { (for cooked dishes) }\end{array}$ & $\begin{array}{l}\text { Wash, drain and pat dry with paper } \\
\text { towels. Wrap a few sprigs or leaves in } \\
\text { freezer wrap and place in a freezer } \\
\text { bag. Seal and freeze. }\end{array}$ & $\begin{array}{ll}---- \\
\end{array}$ \\
\hline Kohlrabi & $\begin{array}{l}\text { Select stems when fully grown but } \\
\text { tender. Cut off tops and roots. Wash } \\
\text { and peel off the tough bark. Leave } \\
\text { whole or dice in } 1 / 2 \text { inch cubes. } \\
\text { Blanch, cool promptly, and drain. } \\
\text { Package, seal and freeze. }\end{array}$ & $\begin{array}{l}\text { Whole - } 3 \text { minutes } \\
\text { Cubes - } 1 \text { minute }\end{array}$ \\
\hline Mushrooms & $\begin{array}{l}\text { Choose mushrooms free of spots. Sort } \\
\text { by size; wash and trim ends. For better } \\
\text { color, soak } 5 \text { minutes in a solution of } 1 \\
\text { pint water and } 1 \text { teaspoon lemon or } \\
1-1 / 2 \text { teaspoons citric acid. Blanch, } \\
\text { cool and drain. } \\
\text { Optional Method-Sauté in butter or } \\
\text { margarine until tender. Package, seal } \\
\text { and freeze. }\end{array}$ & $\begin{array}{l}\text { In steam - } 5 \text { minutes } \\
\text { Buttons or quarters - 3-1/2 } \\
\text { minutes } \\
\text { Slices - } 3 \text { minutes }\end{array}$ \\
\hline
\end{tabular}




\begin{tabular}{|c|c|c|}
\hline Vegetable & Preparation & $\begin{array}{c}\text { Blanching Time } \\
\text { (in boiling water unless } \\
\text { otherwise stated) } \\
\end{array}$ \\
\hline Okra & $\begin{array}{l}\text { Wash pods and separate into small } \\
\text { pods ( } 4 \text { inches or less) and large pods. } \\
\text { Remove the stems at the end of the } \\
\text { seed cells, being careful not to expose } \\
\text { the seed cells. Blanch, cool, and drain. } \\
\text { Leave whole or slice crosswise. } \\
\text { Package, seal and freeze. } \\
\text { For Frying-Slice blanched pods } \\
\text { crosswise and dredge with flour or } \\
\text { meal. Spread in a single layer on a } \\
\text { shallow pan. Freeze just until firm. } \\
\text { Package, seal and freeze. }\end{array}$ & $\begin{array}{l}\text { Small pods- } 3 \text { minutes } \\
\text { Large pods- } 4 \text { minutes }\end{array}$ \\
\hline $\begin{array}{l}\text { Onions } \\
\text { (for cooked dishes only) }\end{array}$ & $\begin{array}{l}\text { Choose mature bulbs and clean as for } \\
\text { eating. Blanch, cool promptly, and } \\
\text { drain. Package, seal and freeze. }\end{array}$ & $\begin{array}{l}3 \text { to } 7 \text { minutes or until center } \\
\text { is heated }\end{array}$ \\
\hline Green Onions & $\begin{array}{l}\text { Young green onions may be chopped } \\
\text { for salads and sandwiches and frozen } \\
\text { without blanching, but they will not be } \\
\text { crisp. They will be highly flavored but } \\
\text { may be slightly tough. }\end{array}$ & ----- \\
\hline Onion Rings & $\begin{array}{l}\text { Wash, peel and slice onions. Separate } \\
\text { into rings. Blanch, cool promptly, drain } \\
\text { and coat with flour. Dip in milk. Coat } \\
\text { with a mixture of equal parts cornmeal } \\
\text { and pancake mix. Arrange in a single } \\
\text { layer on a tray. Freeze. Pack into } \\
\text { containers using plastic wrap to } \\
\text { separate the layers. Seal and freeze. } \\
\text { To serve, fry frozen rings in } 375^{\circ} F \text { oil } \\
\text { until golden brown. }\end{array}$ & 10 to 15 seconds \\
\hline $\begin{array}{l}\text { Peas: edible pod } \\
\text { (snow, sugar, sugar snap or } \\
\text { Chinese) }\end{array}$ & $\begin{array}{l}\text { Choose table-ready, tender pods. } \\
\text { Wash, remove blossom ends and } \\
\text { strings. Leave whole. Blanch, cool and } \\
\text { drain. Package, seal and freeze. }\end{array}$ & $\begin{array}{l}\text { Small pods - } 1-1 / 2 \text { minutes } \\
\text { Medium pods }-2 \text { minutes }\end{array}$ \\
\hline Peas: field & $\begin{array}{l}\text { Wash pods, shell, blanch, cool and } \\
\text { drain. Package, seal and freeze. }\end{array}$ & 2 minutes \\
\hline Peas: green & $\begin{array}{l}\text { Pick sweet and tender table-ready } \\
\text { peas. Shell, blanch, cool and drain. } \\
\text { Package, seal and freeze. }\end{array}$ & $1-1 / 2$ minutes \\
\hline
\end{tabular}




\begin{tabular}{|c|c|c|}
\hline Vegetable & Preparation & $\begin{array}{c}\text { Blanching Time } \\
\text { (in boiling water unless } \\
\text { otherwise stated) }\end{array}$ \\
\hline Peppers: hot & $\begin{array}{l}\text { Wash and remove stems. Package, } \\
\text { seal and freeze. }\end{array}$ & ---- \\
\hline Peppers: sweet & $\begin{array}{l}\text { Wash, cut in half, remove stems and } \\
\text { seeds. If desired, cut into 1/2-inch } \\
\text { strips or rings. } \\
\text { For Use in Cooked Dishes-Blanch, } \\
\text { cool and drain. Package, seal and } \\
\text { freeze. } \\
\text { For Use in Uncooked or Cooked } \\
\text { Foods-Do not blanch. Package, seal } \\
\text { and freeze. }\end{array}$ & $\begin{array}{l}\text { Halves - } 3 \text { minutes } \\
\text { Strips or rings - } 2 \text { minutes }\end{array}$ \\
\hline Peppers: pimiento & $\begin{array}{l}\text { Peel by roasting in oven at } 400^{\circ} \text { to } \\
450^{\circ} \mathrm{F} \text { for } 6 \text { to } 8 \text { minutes or until skins } \\
\text { can be rubbed off. Wash off charred } \\
\text { skins, remove stems and seeds. } \\
\text { Package, seal and freeze. }\end{array}$ & $\begin{array}{ll}---- \\
\end{array}$ \\
\hline Potatoes: Irish & $\begin{array}{l}\text { Select new potatoes directly from the } \\
\text { garden. Peel or scrape and wash. } \\
\text { Blanch and cool. Package, seal and } \\
\text { freeze. } \\
\text { For French Fries-Wash and peel } \\
\text { mature potatoes. Cut into } 1 / 3 \text {-inch by } \\
3 / 8 \text {-inch strips. Rinse in cold water. Dry } \\
\text { thoroughly. Deep fry in hot fat }\left(360^{\circ} \mathrm{F}\right) \\
\text { for about } 5 \text { minutes until tender but not } \\
\text { brown. Drain and cool. Package, seal } \\
\text { and freeze. To serve, heat in a } 475^{\circ} \mathrm{F} \\
\text { oven until golden brown. }\end{array}$ & 3 to 5 minutes \\
\hline Pumpkin & See Winter Squash & 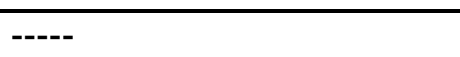 \\
\hline Rutabagas & $\begin{array}{l}\text { Select young, medium-sized } \\
\text { rutabagas. Cut off tops, wash and peel. } \\
\text { Cubed-Cut into cubes, blanch, cool, } \\
\text { and drain. Pack, seal and freeze. } \\
\text { Mashed-Cut into chunks and cook } \\
\text { until tender in boiling water. Drain, } \\
\text { mash, and cool. Pack into containers, } \\
\text { seal and freeze. }\end{array}$ & Cubed - 3 minutes \\
\hline
\end{tabular}




\begin{tabular}{|c|c|c|}
\hline Vegetable & Preparation & $\begin{array}{c}\text { Blanching Time } \\
\text { (in boiling water unless } \\
\text { otherwise stated) }\end{array}$ \\
\hline $\begin{array}{l}\text { Chayote Squash } \\
\text { (Vegetable Pear) }\end{array}$ & $\begin{array}{l}\text { Select those with tender skins. Wash, } \\
\text { remove stem and blossom end. Do not } \\
\text { pare. Dice, removing seed. Blanch, } \\
\text { cool and, drain. Package, seal and } \\
\text { freeze. }\end{array}$ & 2 minutes \\
\hline \multirow[t]{2}{*}{$\begin{array}{l}\text { Summer Squash } \\
\text { (including Zucchini) }\end{array}$} & $\begin{array}{l}\text { Select young tender squash. Wash } \\
\text { and cut into } 1 / 2 \text {-inch slices. Blanch, } \\
\text { cool and drain. Package, seal and } \\
\text { freeze. }\end{array}$ & 3 minutes \\
\hline & $\begin{array}{l}\text { Grated Zucchini for Baking-Steam in } \\
\text { small quantities until translucent. Pack } \\
\text { in amounts used in recipes, allowing } \\
\text { headspace. Put containers in cold } \\
\text { water to cool. Seal and freeze. Drain } \\
\text { before using in baking. }\end{array}$ & In steam - 1-2 minutes \\
\hline $\begin{array}{l}\text { Winter Squash (including } \\
\text { spaghetti squash) and } \\
\text { Pumpkin }\end{array}$ & $\begin{array}{l}\text { Select mature squash or pumpkin. } \\
\text { Wash, cut into small pieces and } \\
\text { remove seeds. Cook until soft in boiling } \\
\text { water, in steam, or in } 350^{\circ} \mathrm{F} \text { oven. } \\
\text { Remove pulp from rind. Mash, cool, } \\
\text { package and freeze. }\end{array}$ & Cook until tender. \\
\hline Sweet Potatoes & $\begin{array}{l}\text { Wash and sort sweet potatoes } \\
\text { according to size. Cook until tender in } \\
\text { water, steam or in the oven. Cool, peel } \\
\text { and cut in halves, slice or mash. To } \\
\text { prevent whole or sliced sweet potatoes } \\
\text { from darkening, dip for } 5 \text { seconds in a } \\
\text { solution of } 1 \text { tablespoon citric acid or } \\
1 / 2 \text { cup lemon juice per quart of water. } \\
\text { To prevent mashed sweet potatoes } \\
\text { from darkening, mix } 2 \text { tablespoons } \\
\text { orange or lemon juice with each quart } \\
\text { of mashed sweet potatoes. Package, } \\
\text { seal and freeze. }\end{array}$ & 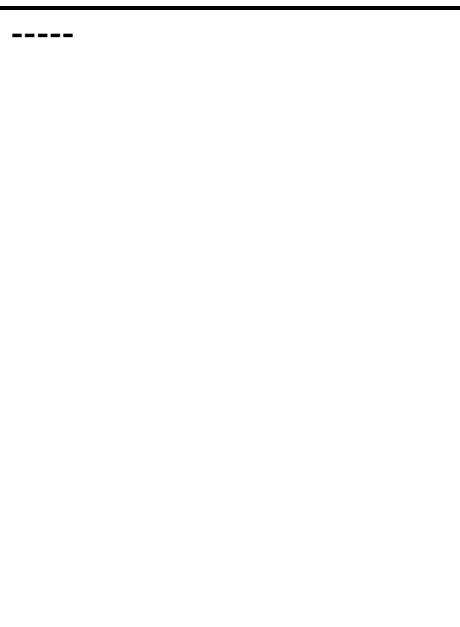 \\
\hline Tomatoes & $\begin{array}{l}\text { Wash; dip in boiling water for } 30 \\
\text { seconds to loosen skins. Peel, core, } \\
\text { leave whole or cut in pieces. Package, } \\
\text { seal and freeze. }\end{array}$ & $\begin{array}{ll}---- \\
\end{array}$ \\
\hline
\end{tabular}




\begin{tabular}{|c|c|c|}
\hline Vegetable & Preparation & $\begin{array}{c}\text { Blanching Time } \\
\text { (in boiling water unless } \\
\text { otherwise stated) } \\
\end{array}$ \\
\hline Tomato juice & $\begin{array}{l}\text { Wash and trim tomatoes. Cut into } \\
\text { quarters or eighths. Simmer } 5 \text { to } 10 \\
\text { minutes. Press through a sieve. Cool, } \\
\text { package, seal and freeze. }\end{array}$ & ----- \\
\hline Tomatoes, stewed & $\begin{array}{l}\text { Remove stems, peel, and quarter ripe } \\
\text { tomatoes. Cover and cook until tender } \\
\text { (10 to } 20 \text { minutes). Cool, package, seal } \\
\text { and freeze. }\end{array}$ & 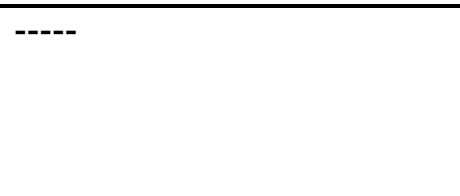 \\
\hline Green Tomatoes & $\begin{array}{l}\text { Select firm, sound green tomatoes. } \\
\text { Wash, core, and slice } 1 / 4 \text {-inch thick. } \\
\text { For Frying-Pack the slices into } \\
\text { containers with freezer wrap between } \\
\text { the slices. Seal and freeze. }\end{array}$ & $\begin{array}{ll}---- \\
\end{array}$ \\
\hline Turnips & $\begin{array}{l}\text { Select small to medium, firm, mild- } \\
\text { flavored turnips. Wash, peel and cut } \\
\text { into } 1 / 2 \text {-inch cubes. Blanch, cool and } \\
\text { drain. Package, seal and freeze. }\end{array}$ & 2 minutes \\
\hline
\end{tabular}

